\title{
Tectonics
}

\author{
RESEARCH ARTICLE \\ 10.1029/2019TC005903 \\ Key Points: \\ - The presence of a weak \\ pre-extensional evaporitic layer \\ delays the growth of orogenic wedge \\ - In presence of an intermediate thick \\ salt layer the orogen develops an \\ antiformal stack in the deep crust \\ - Important amount of salt leads to \\ the quasi-absence of topography and \\ widespread salt tectonics \\ obliterating thrusts propagation
}

Supporting Information:

- Supporting Information S1

- Figure S1

- Figure S2

- Figure S3

Correspondence to:

A. Jourdon,

jourdon_anthony@hotmail.fr

Citation:

Jourdon, A., Mouthereau, F., Le Pourhiet, L., \& Callot, J.-P. (2020). Topographic and tectonic evolution of mountain belts controlled by salt thickness and rift architecture.

Tectonics, 39, e2019TC005903. https:// doi.org/10.1029/2019TC005903

Received 30 SEP 2019

Accepted 24 DEC 2019

Accepted article online 3 JAN 2020

(c)2020. American Geophysical Union. All Rights Reserved.

\section{Topographic and Tectonic Evolution of Mountain Belts Controlled by Salt Thickness and Rift Architecture}

\author{
Anthony Jourdon ${ }^{1,2}$, Frédéric Mouthereau ${ }^{1}$, Laetitia Le Pourhiet ${ }^{2}$, and Jean-Paul Callot ${ }^{3}$ \\ ${ }^{1}$ CNRS, GET, Université Paul Sabatier, Toulouse, France, ${ }^{2}$ Sorbonne Université, CNRS-INSU, Institut des Sciences de la \\ Terre Paris, ISTeP UMR, Paris, France, ${ }^{3}$ E2S UPPA, LFCR, Université de Pau \& Pays Adour, Pau, France
}

\begin{abstract}
The role of the heterogeneous rheological architecture of rifted margins in the building of mountain belts has challenged our view of how a collisional orogen formed. We show, using two-dimensional numerical experiments of collision built by the inversion of rifted margins, that a weak pre-extensional evaporitic layer delays the growth of topography and the onset of syn-orogenic sedimentary record in foreland basins. In tectonic models lacking a weak décollement layer, the orogen grows by progressive accretion of basement thrusts. With a 2-km-thick salt layer, the orogen develops an antiformal stack in the deep crust that is kinematically connected to a shallow thin-skin thrust belt in the foreland as observed in many orogens. A 5-km-thick weak layer leads to the quasi-absence of topography and widespread salt tectonics and obliterates thrusts propagation while promoting crust and mantle underthrusting. During convergence, the preservation of a marine seaway emphasizes that collision may involve a significant period of submarine continental accretion, which duration is controlled by the thickness of the weak décollement layer. From these experiments we infer that the thicker the salt layer, the longer the delay between the onset of far-field shortening and the formation of the orogen. Our study explains first-order features recognized in many orogens controlled by variable salt thickness and extension.
\end{abstract}

\section{Introduction}

Salt-rock deposits are common features of sedimentary basins, particularly the Triassic deposits of the PeriTethyan and Atlantic realms (Soto et al., 2017). Their physical properties offer a mechanical decoupling level, facilitate heat conduction, and result in complex geometries in rift basin deposits (Brun \& Fort, 2011; Gradmann \& Beaumont, 2017; Rowan, 2014) and fold-and-thrust belts (Callot et al., 2012; Granado et al., 2019; Legeay et al., 2018). In rift basins, numerical models show that mechanical decoupling due to a prerift salt layer leads to fast crustal extraction and mantle exhumation associated with the formation of sag basins and high thermal regime in overlying sediments (Duretz et al., 2019). Observations of natural examples coupled with analog and numerical models of salt-detached fold-and-thrust belts show that a prekinematic salt level promotes thin-skin tectonics, rapid propagation of the deformation front, and lack of dominant thrust vergence and results in an extremely flat cross-sectional taper at the origin of wedge-top basins (Davis \& Engelder, 1985; Ford, 2004; Smit et al., 2003). Most studies have focused on the external domains of collisional orogens where pre- to syn-tectonic basins are preserved. Thus, the role of salt properties on the temporal evolution of the deep structure and topography of the inner part of orogenic domains remains unexplored.

To fully account for large-scale effects of salt behavior on mountain belt development, a lithosphere-scale approach dealing with a complete Wilson cycle, from rifting to mountain building, is required. Hence, we conduct a series of two-dimensional numerical experiments in which we explore the impacts of a weak mechanical layer on the topographic evolution and on the strain localization. We compare numerical experiments results with natural examples from the Pyrenees, where prerift Triassic salt rocks have been involved during successive mid-Cretaceous rifting and Cenozoic collisional phases (Càmara \& Flinch, 2017; McClay et al., 2004; Saura et al., 2016). We show that the tectonic inversion of salt-based rift basins increases the delay between the onset of plate convergence and first sedimentary record of mountain building in foreland basins. This delay observed between the onset of convergence and growth of orogenic topography is a first-order feature in orogens, but no satisfactory explanation was provided to explain it. We also show that longwavelength and low-amplitude topography that characterizes salt-controlled orogens further explains why syn-tectonic marine deposition conditions may be maintained close to collision suture zone despite significant shortening already took place. 


\section{Numerical Experiments, Code, and Model Setup}

Our numerical experiments consider a full Wilson Cycle. The initial rifting phase allows the formation of physically consistent passive margins and extensional structures that may be involve in the later mountain building phase (Buiter et al., 2009; Jammes \& Huismans, 2012; Jourdon et al., 2019). A constant extension rate of $5 \mathrm{~mm} /$ year is imposed during a $30 \mathrm{Myr}$ phase of rift formation. From 30 to $32.5 \mathrm{Myr}$, the extension velocity then linearly decreases to reach zero. A transitional period of tectonic inversion from 33 to 35 Myr is defined by linearly increasing again the convergence rate to reach a constant convergence velocity of $2.5 \mathrm{~mm}$ /year. The magnitude of the boundary conditions during extension corresponds to the formation of magma-poor hyperextended margins ( $<1 \mathrm{~cm} / \mathrm{a}$; e.g., Brune et al., 2014; Jourdon et al., 2019; Lavier \& Manatschal, 2006). The value of $5 \mathrm{~mm} / \mathrm{a}$ represents a good approximation for the Pyrenean rifting phase (Jourdon et al., 2019) while the timing and magnitude of the shortening are designed to fit the first-order timing of Pyrenean collision (e.g., Espurt et al., 2019; Mouthereau et al., 2014).

The numerical simulations are performed using pTatin2D, a parallel implementation of a finite element method. It employs an Arbitrary Lagrangian-Eulerian discretization, together with the material point method to solve the governing conservation equations of momentum, mass, and energy in incompressible flow (May et al., 2014, 2015). Brittle parts of the lithosphere are simulated using a Drucker-Prager yield criterion adapted to continuum mechanics. Viscous domains are simulated with Arrhenius flow laws (Table S1 in the supporting information) except for the salt that is kept at a constant $10^{19} \mathrm{~Pa}$.s viscosity, representing a 6 order of magnitude difference with the strongest parts of the lithosphere.

Figure 1 describes the geometry and thermomechanical initial state of our reference model. We consider a domain of $600 \times 400 \mathrm{~km}$, including a prerift sediment layer, a salt layer, an upper and a lower crust, and a lithospheric and asthenospheric mantle. Thickness of the salt layer represents the investigated parameter between our three models (no salt, 2 and $5 \mathrm{~km}$ thick).

The initial temperature field is computed with a steady-state solution of the heat equation considering a $600{ }^{\circ} \mathrm{C}$ Moho temperature, a radiogenic heat production, and an adiabatic gradient of $0.5{ }^{\circ} \mathrm{C} / \mathrm{km}$ in the asthenosphere. In order to facilitate strain localization in the center of the domain, a thermal anomaly of $50{ }^{\circ} \mathrm{C}$ is prescribed (Figure 1) at Moho depths and attenuates toward the surface. Boundary conditions to solve the energy conservation are $0{ }^{\circ} \mathrm{C}$ on the surface, $1,400{ }^{\circ} \mathrm{C}$ at the bottom, and null heat fluxes on the sides.

Velocity boundary conditions are imposed on both lateral sides of the model and at the bottom to maintain constant the amount of material in the model domain. To account for erosion and sedimentation processes, the topography is modeled by using a free surface on which a simple diffusion law is applied (Culling, 1965).

Particles insertion upon the surface allows tracking topographic changes and sedimentation (Jourdon et al., 2018; all models parameters are available in Table S2).

\section{Tectonic Styles and Strain Distribution}

Figures 2, 3, and 4 show model results after $150 \mathrm{~km}$ of extension and 12, 65, and $135 \mathrm{~km}$ of shortening, respectively, for the model without salt, with 2- and 5-km-thick décollement layer. In the model without salt, the deformation during extension localizes along normal faults rooting at the middle-lower crust boundary in a shallow-dipping viscous shear zone. During the crustal thinning, a low-angle detachment exhumed the mantle through the crust and progressively reaches the surface (Figures $2 \mathrm{a}$ and $2 \mathrm{~b}$ ) when crustal breakup occurs. Disconnected sedimentary basins develop along the normal faults of the necking domain on both margins during the continental rifting phase. These basins represent typical syn-tectonic sedimentary deposits of 2- to 4-km thickness. In the central part of the rift, the sedimentary basin is wide $(\sim 30 \mathrm{~km})$ and thin $(\sim 2$ $\mathrm{km})$ on the lower plate, while it is narrower $(\sim 20 \mathrm{~km})$ and thicker $(\sim 5 \mathrm{~km})$ on the upper plate above the exhumed mantle. The asymmetric shape of this basin can be related to the structural asymmetry between the two margins. On the upper plate, a steep normal fault controls the depth of the basin, while on the lower plate the shallow dipping detachment leads to a low tectonic subsidence.

Immediately after the onset of plate convergence, the reactivation of former extensional shear zones on the lower plate margin (Figures $2 \mathrm{c}$ and $2 \mathrm{~d}$ ) leads to the formation of a typical thick-skinned crustal nappe stack 


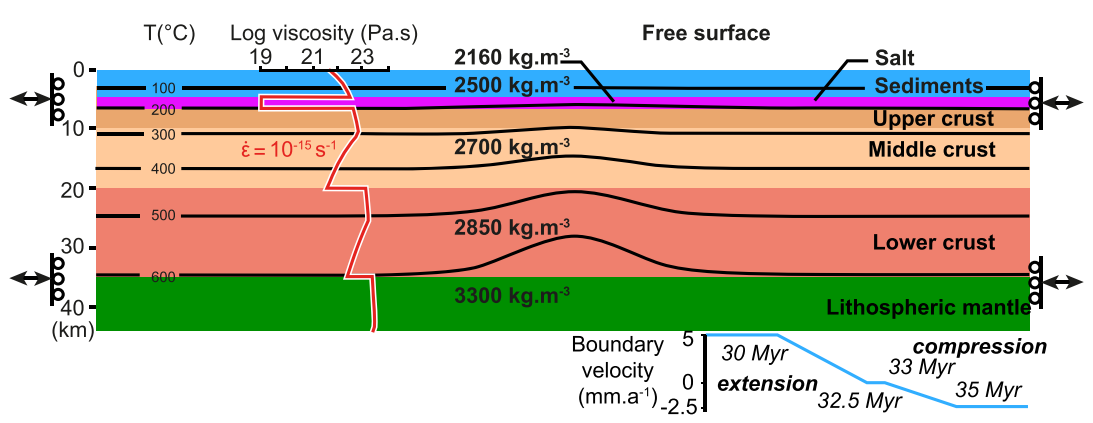

Figure 1. Numerical models setup geometry, parameters, and boundary conditions. The red curve represents the viscosity profile of simulated rheologies for a strain rate of $10^{-15} \mathrm{~s}^{-1}$ (see equations (A8)-(A10)) and the initial geotherm. Black lines show the initial geotherm and its anomaly in the center of the model. The blue curve beneath the model geometry represents the boundary velocity variation during the simulations.

(Figures 2e and 2f). As the orogenic load progresses outward, a flexural basin develops on the lower plate, trapping syn-orogenic sediments close to the mountain front that are then incorporated in the deformed domain and eroded as the prism widens. During the last stages of shortening (Figures $2 \mathrm{~g}$ and $2 \mathrm{~h}$ ), the increasing mantle overthrusting and backward rotation of formerly accreted crustal units result in the development of a retro-foreland basin on the syn-rift series that are well preserved in the upper plate.

For models with salt (Figures 3 and 4), specific salt-related features including minibasins and rollover structures are observed during the rifting phase. The mobility of salt generates salt depleted areas on horst structures and salt accumulation in grabens that represent inherited geometric and mechanical features of major importance during the stage of tectonic inversion.

The model with an initially 2-km-thick weak salt layer displays two major extensional crustal shear zones on the edges of the growing rift, the upper one in the salt layer and the deeper one in the middle crust (Figures $3 \mathrm{a}$ and $3 \mathrm{~b}$ ). Beneath the central basin, the crust is removed by lateral extraction along the weak salt décollement and a wide syn-rift sag basin develops (100 km wide, $5 \mathrm{~km}$ thick; Figure 3a). During the rifting phase, although the upper crust and the uppermost part of the middle crust experience plastic deformation beneath the salt layer (see the deformation map on Figure S2), the deformation mostly localizes in the salt layer, favoring the formation of shallow-dipping detachments instead of steep brittle faults. Hence, the sedimentary basins developing in the necking domain remain thin ( 800 $\mathrm{m}$ to $1 \mathrm{~km}$ thick) and wide $(\sim 30 \mathrm{~km})$ on both margins. The central sag basin displays a spatial and temporal evolution of its depocenter. Three depocenters can be identified (Figure 3a), and the migration of the depocenter can be directly related to the activation of the mantle detachments (Figures 3a, 3b, and S2).

During the shortening phase, two decoupling levels are activated in the former rifted margin. The salt layer offers a first decoupling level between the upper crust and the sediments, while the base of the middle crust is decoupled from the stronger lower crust. Those two décollement levels allow strain localization and promote the underthrusting of the most distal margin below the former sag basin with little internal deformation (Figures $3 \mathrm{c}$ and $3 \mathrm{~d}$ ). The underthrusting of the lower plate lasts until the deformation front reaches the salt pinch-out in the prowedge foreland (Figures $3 \mathrm{c}-3 \mathrm{e}$ ). From that point on, crustal thickening and shortening of the proximal margin occur (Figures 3e and 3f), which in turn enhances faster orogenic growth. The delay between the onset of plate convergence and the onset of midcrustal thrusting (occurring at $\sim 60$ Myr) is around 20 Myr. During this time interval, thin sedimentary basins (2-3 km thick) develop on the upper plate above the shallow-dipping thrust localized in the salt layer. Around $60 \mathrm{Myr}$, the onset of crustal shortening corresponds to the initiation of an important influx of sediments toward the prowedge foreland basins (Figure 3e) that rapidly accumulate in a thick flexural basin (up to $10 \mathrm{~km}$ thick at $70 \mathrm{M}$, Figure 3e). This timing strongly differs with the model without salt, in which the prowedge foreland basin develops instantaneously. The superposition of two highly localized shear zones in the extremely weak salt décollement and in the middle crust produces crustal duplexing in the deep root of the orogen (Figures $3 g$ and $3 \mathrm{~h}$ ). The antiformal stacking of crustal units folds uppermost crustal units and tilts the prowedge foreland deposits (Figure 3g). A midcrustal ramp then connects to the salt detachment in the shallow crust below the prowedge foreland basin (Figures $3 \mathrm{~g}$ and $3 \mathrm{~h}$ ). The prowedge foreland depicts typical thin-skinned 

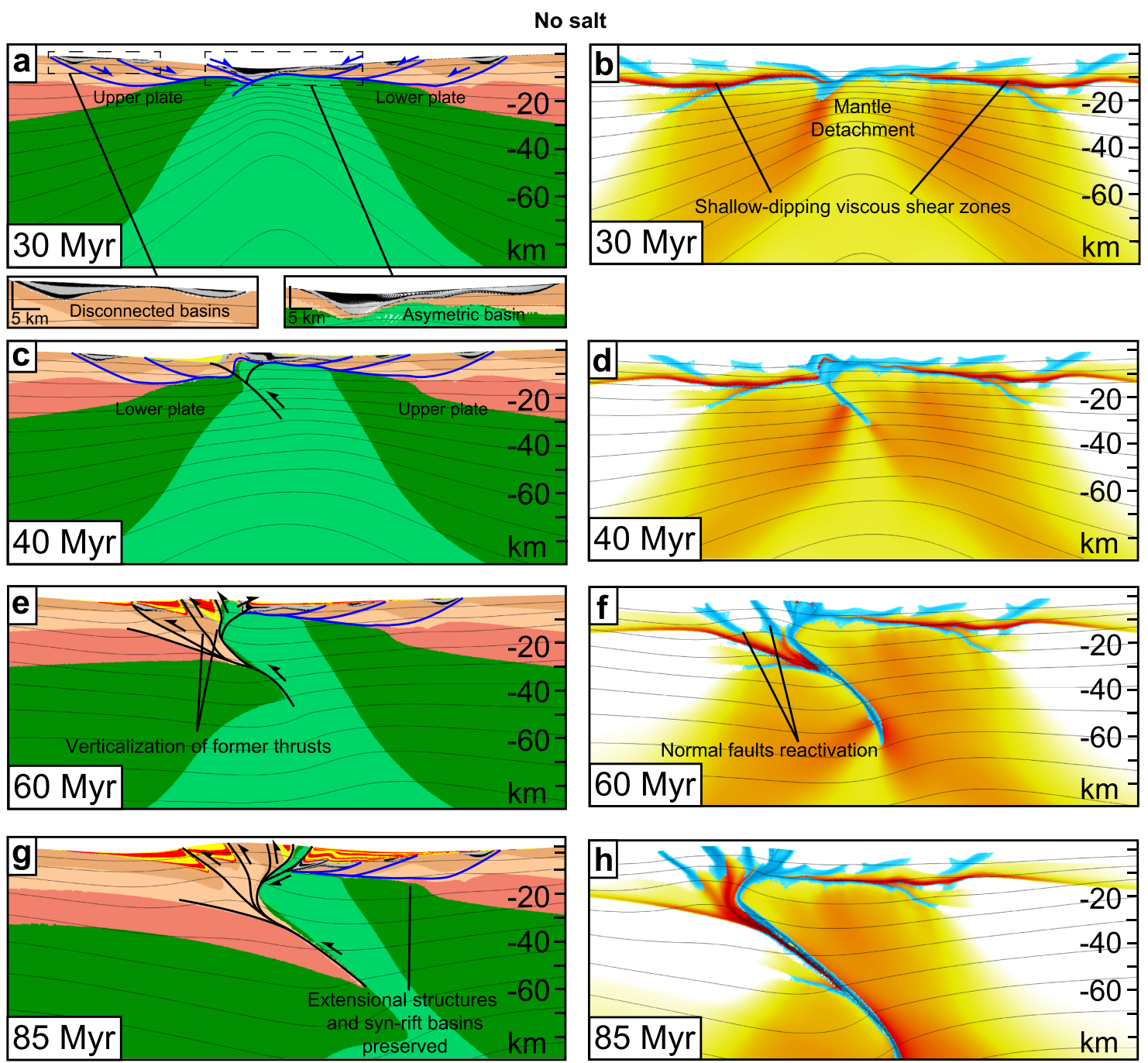

- Contractional shear zones

- Extensional shear zones
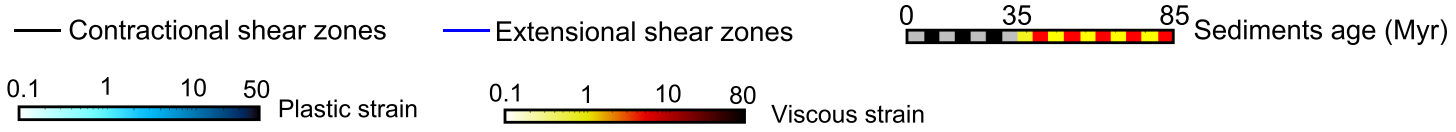

Figure 2. Model without salt results at $30 \mathrm{Myr}(\mathrm{a}$ and b), $40 \mathrm{Myr}(\mathrm{c}$ and d), $60 \mathrm{Myr}$ (e and f), and $85 \mathrm{Myr}$ ( $\mathrm{g}$ and h). The left panels show the results for different time steps, and the right panels represent the plastic strain (deformation related to equation (A9)) and viscous strain (deformation related to equation (A8)). Those snapshots display an extension of $150 \mathrm{~km}$ and a global amount of shortening of 12, 75, and $135 \mathrm{~km}$, respectively. Syn-rift sediments are colored in black and gray, while syn-orogenic sediments are colored in red and yellow. The thin black lines represent the isotherms regularly spaced every $100{ }^{\circ} \mathrm{C}$.

tectonics and formation of piggyback basins, while the passive transport of the former syn-rift basins along the salt layer characterizes the retro-wedge foreland evolution (Figure 3g). A major unconformity develops in the syn-orogenic series shaping the evolution of a retro-wedge piggyback basin. Because deep crustal units are exhumed and uplifted faster, differential movement at the rear of the retro-foreland results in normal faulting (Figure 3g).

The model with a 5-km-thick décollement represents an end-member case marked by widespread salt tectonics deformation (Figure 4). Both the extension and shortening phases present specific features related to salt tectonics, such as minibasins, rollover basins, and diapirs, accommodating gravitational gliding of the sedimentary cover. The main characteristics of this model lies in (1) the great efficiency of the detachment faults controlling the mantle exhumation during rifting, leading to narrow and weakly deformed margins (Figure 4a), and (2) the absence of crustal shortening and thickening despite its underthrusting, and a widely distributed deformation in the salt and sedimentary cover (Figure 4). The large amount of salt accommodates 


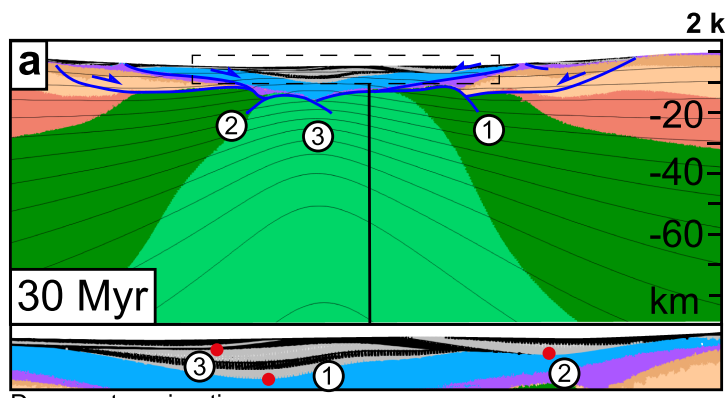

2 km salt

Depocentre migration
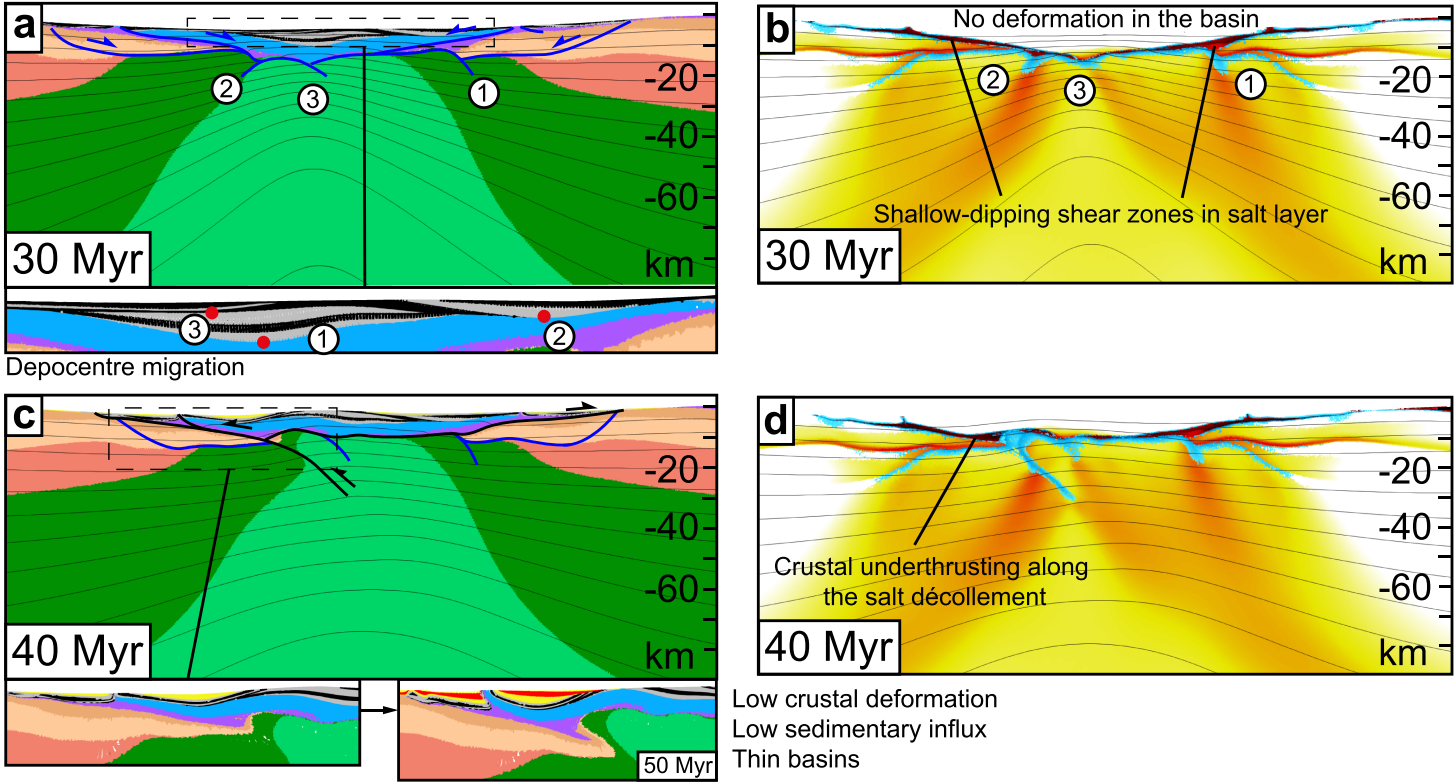

Low crustal deformation

Low sedimentary influx

Thin basins
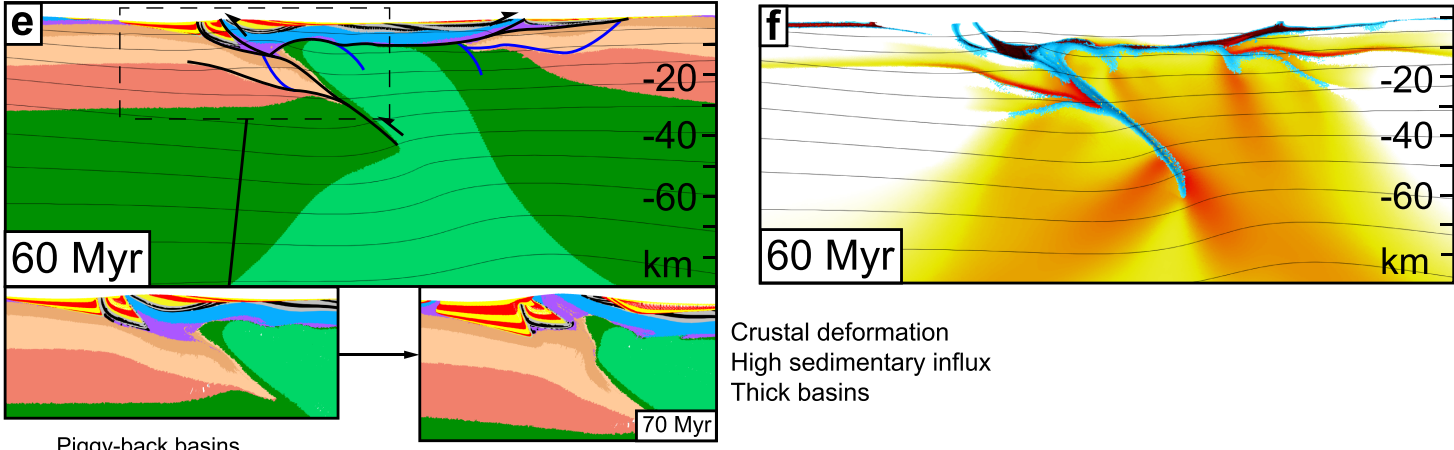

Crustal deformation

High sedimentary influx

Thick basins
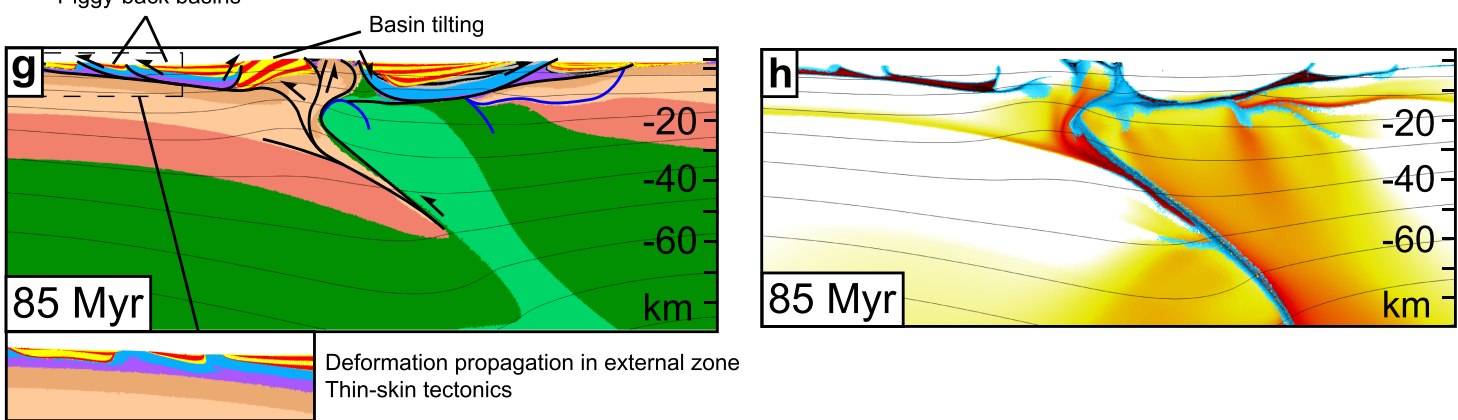

- Contractional shear zones

-Extensional shear zones

$\begin{array}{ll}0 & 35\end{array}$

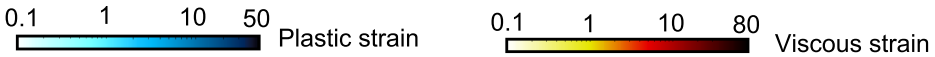

Figure 3. Model with 2-km salt décollement results at $30 \mathrm{Myr}$ (a and b), $40 \mathrm{Myr}$ (c and d), $60 \mathrm{Myr}$ (e and f), and $85 \mathrm{Myr}$ ( $\mathrm{g}$ and $\mathrm{h}$ ). The left panels show the results for different time steps, and the right panels represent the plastic strain (deformation related to equation (A9)) and viscous strain (deformation related to

equation (A8)). Those snapshots display an extension of $150 \mathrm{~km}$ and a global amount of shortening of 12, 75, and $135 \mathrm{~km}$, respectively. Syn-rift sediments are colored in black and gray, while syn-orogenic sediments are colored in red and yellow. The thin black lines represent the isotherms regularly spaced every $100{ }^{\circ} \mathrm{C}$. The numbers in panels a and $\mathrm{b}$ represent the deformation sequence of mantle detachments and the associated depocenter migration in the rift basin.

most of the extensional and compressional deformation. The resulting structures are mostly diapirs (both during extension and shortening phases) and thrust piercement structures (thrust along diapir during shortening) widely distributed all along the cross section along which rollover and minibasins develop (Figures 4a and 4e). 

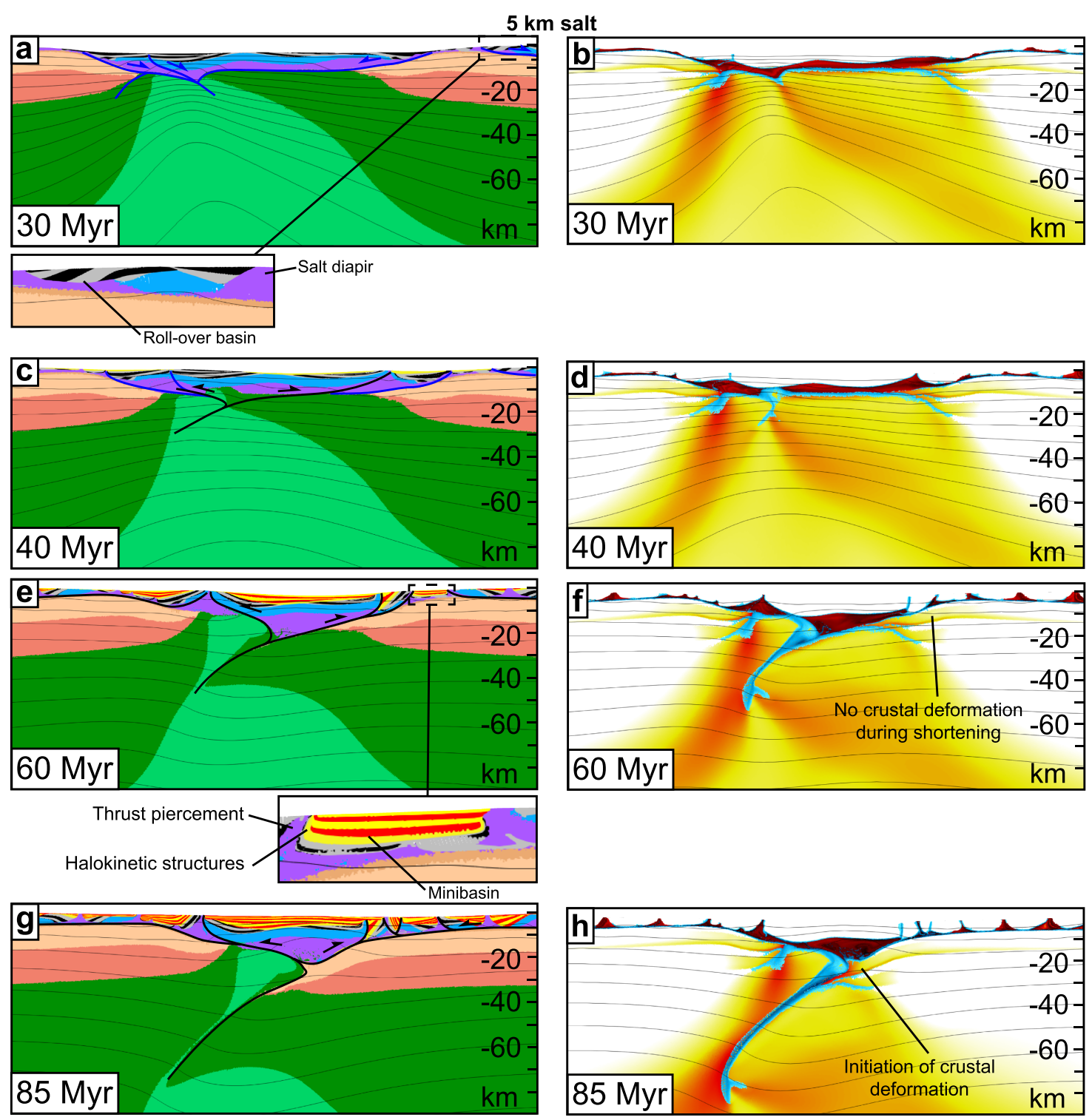

- Contractional shear zones

_Extensional shear zones

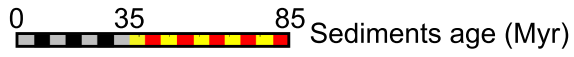

\begin{tabular}{rrrr}
0.1 & 1 & $10 \quad 50$ \\
\hline
\end{tabular}

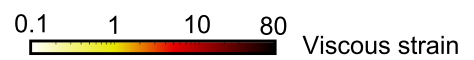

Figure 4. Model with 5-km salt décollement results at $30 \mathrm{Myr}$ (a and b), $40 \mathrm{Myr}$ (c and d), $60 \mathrm{Myr}$ (e and f), and $85 \mathrm{Myr}$ (g and h). The left panels show the results for different time steps, and the right panels represent the plastic strain (deformation related to equation (A9)) and viscous strain (deformation related to equation (A8)). Those snapshots display an extension of $150 \mathrm{~km}$ and a global amount of shortening of 12, 75, and $135 \mathrm{~km}$, respectively. Syn-rift sediments are colored in black and gray, while syn-orogenic sediments are colored in red and yellow. The thin black lines represent the isotherms regularly spaced every $100{ }^{\circ} \mathrm{C}$.

\section{Topographic Evolution}

The contrasting pattern of deformation in each model is further reflected in their different topographic evolution (Figures 5a-5c). During extension, a first-order difference between models is observed: The thicker the salt layer, the wider and the shallower the sedimentary basins. In the experiment without a weak salt interface, the relief between the range and the foreland basins is the largest $(\Delta y=4,000 \mathrm{~m})$. The model with a 2-km-thick salt layer orogen displays a lower relief of $\Delta y=2,000 \mathrm{~m}$, and the $5 \mathrm{~km}$-thick salt layer experiment shows a subsea fold-and-thrust belt. 
Both the experiment without salt and with a 2-km-thick salt layer show uplift in the central syn-rift basin shortly after the onset of contraction (from 40 to $50 \mathrm{Myr}$ ), while the 5-km-thick salt model records uplift on the former rift shoulders (Figure 5c). Then, between 50 and $60 \mathrm{Myr}$ the topography in the central area first decreases and increases again as the orogenic wedge broadens and becomes asymmetric, as shown by the formation of a retro-foreland basin (Figures $5 \mathrm{a}$ and $5 \mathrm{~b}$ ). In the model with 2-km-thick salt layer, the topography remains below sea level until $60 \mathrm{Myr}$. This time window corresponds to the time needed for strain to localize in the lower plate crust, building tectonic loading that results in the increase of sedimentary influx, and the formation of a prowedge foreland basin.

In the model without salt the topography shows a large amplitude $(\Delta y=3,000 \mathrm{~m})$ and a short wavelength $(\lambda=$ $40 \mathrm{~km}$, the distance estimated between the two highest mountain peaks). As the relief increases, the regions with highest elevation migrate toward the lower plate at a velocity/rate comparable with the strain propagation in the orogenic wedge (Figures $5 \mathrm{~d}$ and $5 \mathrm{e}$ ). In the model with a 2-km salt layer, from $60 \mathrm{Myr}$ onward, the presalt basement thickens, resulting in the formation of a topography and associated crustal root (Figure 5g). We note, however, that the amplitude and the wavelength of the topography are, respectively, lower $(\Delta y=$ $2,000 \mathrm{~m})$ and higher $(\lambda=180$ to $200 \mathrm{~km})$ than in the orogen without salt $(\Delta \mathrm{y}=3,000 \mathrm{~m}, \lambda=130$ to 150 $\mathrm{km})$. In opposition with the two previous models, when a $5-\mathrm{km}$-thick salt layer is involved during shortening, the crust is too weak to maintain a typical orogenic topography. Instead of being thickened, the accretionary prism flows laterally (Figures 5h and 5i), and a large depression develops in the center of the belt filled by synorogenic sediments deposited in a marine environment.

\section{Controls of Salt Décollement on Structure and Topographic Evolution of Rift Basins and Mountain Belts}

The two models with a weak salt layer display major structural differences at both rifting and mountain building stages with respect to model that lacks a salt layer. Whereas in model without salt the brittle crust deforms along steep plastic shear zones rooting in viscous levels of the crust during extension, the presence of the salt layer produces shallow dipping detachments that localize strain in the décollement layer. Those structures allow thinning and extracting the crust from the center of the rift (e.g., Duretz et al., 2019). Therefore, only a few brittle faults are formed during extension, which results in a boudinage of the whole crust. The presence of salt therefore explains first-order difference in rifted basin architecture between fault-controlled rifted basin and salt-controlled sag basin. The two models with a salt layer also display the formation of several detachment faults in the mantle. The dips of these structures changes for each new detachment fault emplacement. That mantle deformation and exhumation processes are very similar to the flip-flop dynamics proposed for the ultraslow spreading South West Indian mid-oceanic ridge (Reston \& McDermott, 2011; Sauter et al., 2013).

During the convergence stage, both structural and topographic evolution of the orogen differs between the models. The absence of a décollement layer favors crustal strain localization at the onset of shortening. It also promotes a strong coupling between the crust and the mantle (Burov \& Yamato, 2008; Jammes \& Huismans, 2012), since the mantle is involved in the mountain building from the earliest stages, with a back thrust structure rooted along the main thrust. On the contrary, the models with a salt layer display a lag time between the onset of the shortening and the strain localization in the crust. This delay is even greater when the salt layer is thick. In region of the margin where salt has been preserved, the same décollement level is reactivated during the convergence stage, allowing decoupling between the sediments and the underlying crust and mantle. In the thick salt case, the rifted basin is mechanically decoupled from the mantle and ends up being preserved during most of the phase of mantle subduction. This decoupling, together with the short and narrow stretched crust domain, explains the poor involvement of the crust in the orogenic prism, compared to the no salt model.

The topographic evolution and the sedimentary basins formation are also strongly controlled by the mechanical behavior of the lithosphere. On the one hand, in the complete absence of a décollement layer, the topography first rapidly rises and forms reliefs above the active crustal main thrust. As strain propagates in the prowedge foreland in a distributed manner (between 50 and $60 \mathrm{Myr}$, see strain rate evolution on Figure S1), the topography decays until strain relocalizes at $65 \mathrm{Myr}$. From that point on, deformation propagates at crustal scale to build the orogenic wedge and the associated topography. The sedimentary basins 
related to this topographic growth are located at the front of the crustal thrusts and display thick sedimentary sequences. On the other hand, the presence of a thick décollement layer promotes the underthrusting of the lower plate without involving the crust in the deformation. As a result, topography does not grow. Salt remobilization in diapirs structures helps freeing up space and permits important submarine sedimentary accumulation in the preserved basin. In this thick salt-based wedge, gravitational forces are far more important than the strength of the basal décollement; the wedge is kept subcritical. Such a pattern is predicted for salt-based wedges that are known to slide without important internal shortening and promotes the development flat taper associated to wedge-top basins (Costa \& Vendeville, 2002; Davis \& Engelder, 1985; Ford, 2004; Grelaud et al., 2002; Smit et al., 2003). Finally, the presence of an intermediate thickness décollement layer results in a bimodal dynamic. In the early stages of shortening (40 to $60 \mathrm{Myr}$ ), the presence of salt favors decoupling and sliding of cover and crustal units. The high strain localization in the décollement level delays the crustal thickening, and the thrusts propagate outward faster than the topography grows, resulting in a long time period (>20 Myr) during which the elevation remains low, that is, below sea level (Figures $5 \mathrm{~d}-5 \mathrm{~g}$ ). In the latest stage, the crustal deformation is characterized by an antiformal stacking of crustal units between the lower crust and the salt layer, which is typical of underplating stages in accretionary prisms in presence of two decoupling levels (Konstantinovskaya \& Malavieille, 2011; Malavieille, 2010). The involvement of crustal units causes topographic reliefs to rise and enhances a sedimentary influx resulting in thicker foreland basins (Figure 3e).

\section{Natural Examples of a Salt-Based Orogen: The Pyrenees}

Our models share first-order characteristics with the Pyrenean belt (e.g., Teixell et al., 2018). Geological and geophysical investigations have proven that the Pyrenees, a doubly vergent orogen, formed as a result of the inversion of mid-Cretaceous hyperextended rift from Late Cretaceous to Early Miocene (Clerc \& Lagabrielle, 2014; Jammes et al., 2009; Lagabrielle et al., 2010; Mouthereau et al., 2014; Wang et al., 2016). The presence of the prerift upper Triassic salt (Keuper facies and sometimes Muschelkalk), in which the fold-and-thrust belt is detached, is well documented in the southcentral Pyrenees and the BasqueCantabrian basin (Càmara, 2017; Càmara \& Flinch, 2017; Canérot et al., 2005; Ducoux et al., 2019; Saura et al., 2016). Due to the plate kinematics between Iberia and Europe, and the mobility of the Triassic salt during the Early Cretaceous extension, the Keuper décollement layer is unevenly distributed throughout the Pyrenean rift system (Càmara, 2017; Lagabrielle et al., 2010). The Basque-Cantabrian region of the Pyrenees forms a 100-km-wide mountain belt with a smooth topography, characterized by large open synclines and well-preserved passive salt diapirs and ridges, and associated minibasins (Càmara, 2017). Further East, the Nappes de Marbres, despite a more intense prograde HT metamorphism of mid-Cretaceous age, also shows inherited salt tectonics structures mostly if not completely preserved during subsequent shortening (Ducoux et al., 2019). The scarcity of thrust structures and back thrusts overall defined the Basque-Cantabrian belt as a symmetrical fold-and-thrust belt. In this region, salt thickness varies from $500 \mathrm{~m}$ to more than $2 \mathrm{~km}$ in response to prerift and syn-rift salt tectonics. The central Pyrenees (Mouthereau et al., 2014; Munoz, 1992) and west-central Pyrenees (Teixell et al., 2018; Wang et al., 2016) both show an asymmetrical orogenic wedge. The South Pyrenean Zone of central Pyrenees displays a small amount of salt accumulated during convergence in the Organya Basin (Càmara \& Flinch, 2017; Lopez-Mir et al., 2014; Saura et al., 2016) above the thrusts (Figures 6a, 6f, 6j). To the North, the dominant basementinvolved shortening also highlights that the Triassic salt played a minor role during the crustal shortening (e.g., Vacherat et al., 2016, and Figure 3). In the western Pyrenees, however, the North Pyrenean Zone and the Aquitaine Basin feature a most important amount of salt that strongly influences the deformation (Canérot et al., 2005; Espurt et al., 2019). In addition, while syn-convergence Eocene deposits in the Basque-Cantabrian basin are dominantly characterized by marine environment, they are mixed marine/continental in the west-central Pyrenees and preferentially continental in the central Pyrenees. These contrasting structural features and depositional environment between the central Pyrenees and the Basque-Cantabrian Basin are well reproduced in our models, as shown by the differences that exist between segments of the belt with thick salt layer (Basque-Cantabrian Basin; Figure 6d) and with intermediate salt thickness (Central Pyrenees; Figure 6f). Our experiments therefore embody initial conditions consistent with different salt thickness configuration along the Pyrenean orogeny. 

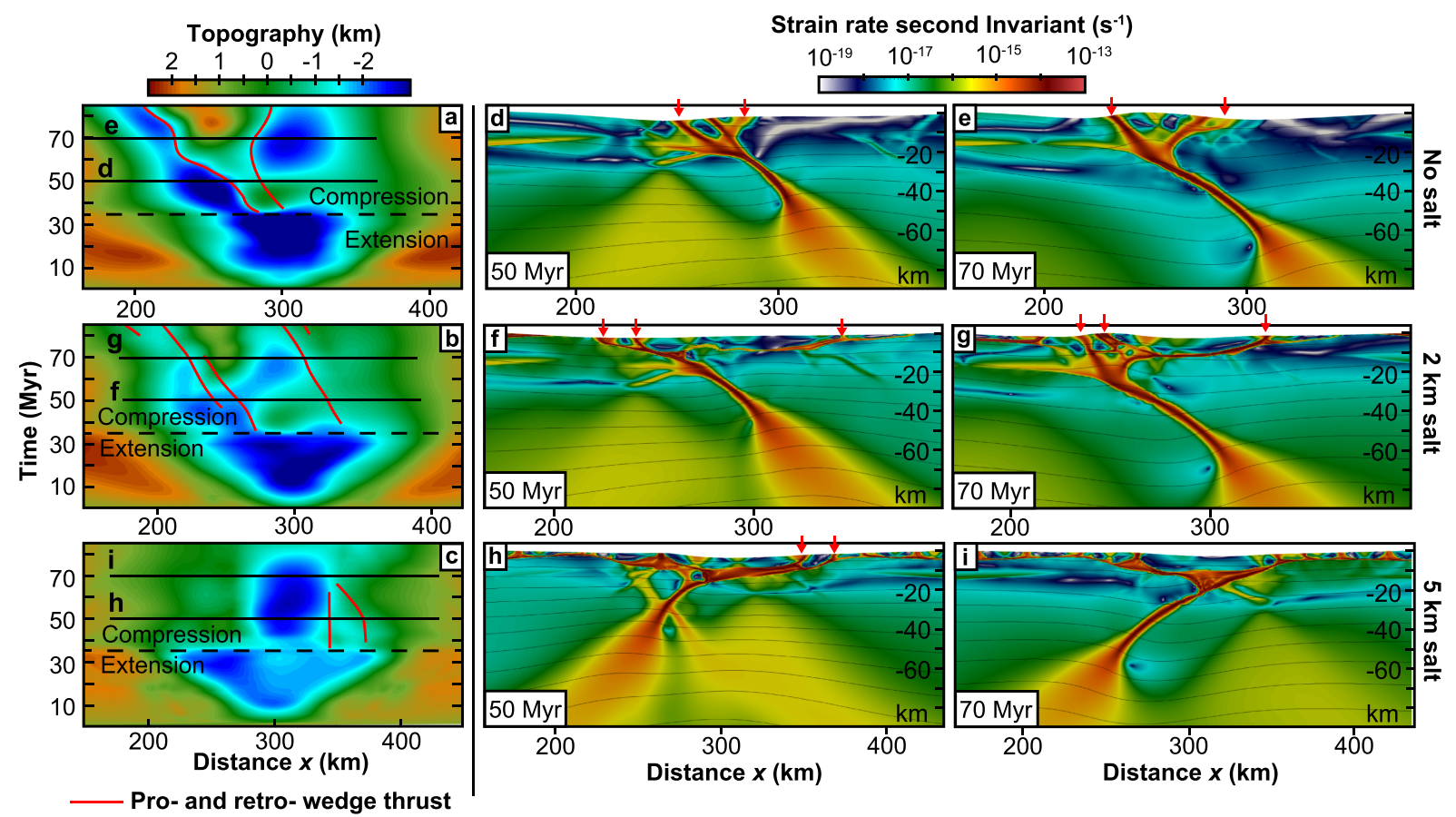

Figure 5. Topographic evolution inferred from our numerical models. The $x$ axis represents the distance along the model surface. The $y$ axis represents the time of the simulations, and the colorscale represents the topographic values. The switch between extensional and compressional boundary conditions is indicated by the dashed line. (a) Model with no salt, (b) model with 2-km-thick salt layer, and (c) model with 5-km-thick salt layer. Filled black lines represent the extent of cross sections at $50 \mathrm{Myr}(\mathrm{d}, \mathrm{f}$, and $\mathrm{h}$ ) and $70 \mathrm{Myr}(\mathrm{e}, \mathrm{g}$, and i). Cross sections represent the second invariant of the strain rate tensor (active nonrotational deformation) for each model. The thin black lines represent the isotherms regularly spaced every $100{ }^{\circ} \mathrm{C}$

Figure 6 shows the final architecture of our model orogens with a thick-salt layer (Figure $6 \mathrm{~h}$ ), an intermediate salt layer (Figure 6j), and without salt (Figure 61). The contrasting nature of plate coupling leads to contrasted orogenic architectures that may be incorrectly interpreted as indicating different collision stages. The presence in our models of a thick and efficient decoupling level in the uppermost crust (i.e., salt-based orogen; Figure 6h) well reproduces the architecture and low topography of the Basque-Cantabrian basin (Figures 6c, 6d, and 6g): The lower plate is underthrusted without significant accretion or internal deformation in the fold-and-thrust belt, and the crust is never exhumed at the surface (Figure 6a). Moreover, in that region, low-temperature thermochronology shows that the first record of exhumation started later in the early-middle Eocene (50-45 Ma; DeFelipe et al., 2019) implying a long period of topographic quiescence after the onset of convergence. Finally, a last line of evidence for the presence of a very thick salt layer is the good preservation of the hyperextended domain as documented by geophysical data in the center of the Basque-Cantabrian basin (Pedrera et al., 2017).

In case of an intermediate or strong coupling, an asymmetrical orogenic crustal wedge developed (Figures $6 \mathrm{j}$ and 61) with a significant relief (Figures 6i and 6k). This case best applies to the central Pyrenees where crustal nappe stacking is documented (Mouthereau et al., 2014; Munoz, 1992). In the Pyrenees, the short time interval between the end of rifting ( $90 \mathrm{Ma}$ ) and the onset of plate convergence ( $84-83 \mathrm{Ma}$ ) has questioned the geodynamic interpretation of the subsidence recorded at this time in peripheral basins that can be thermal (postrift), flexural (syn-convergence), or a combination of both (Angrand et al., 2018). There is also evidence that the onset of subaerial erosion occurred in the Campanian (70 Ma) that is $~ 10 \mathrm{Myr}$ after plate convergence (Mouthereau et al., 2014). The inhibition of crustal stacking due to the presence of a thick salt bearing detachment turns out to provide an explanation to the significant delay of the topographic growth and syn-orogenic sediment production observed in the western Pyrenees. Weak décollement effect on the evolution of topography at the earliest of collision may superimposed on the topographic control by margin architecture recognized in other orogens (Ballato et al., 2010; Mesalles et al., 2014; Mouthereau et al., 2012). Our study suggests that the careful analyses of the stratigraphy and depositional environments can help distinguishing between the controlling factors. 

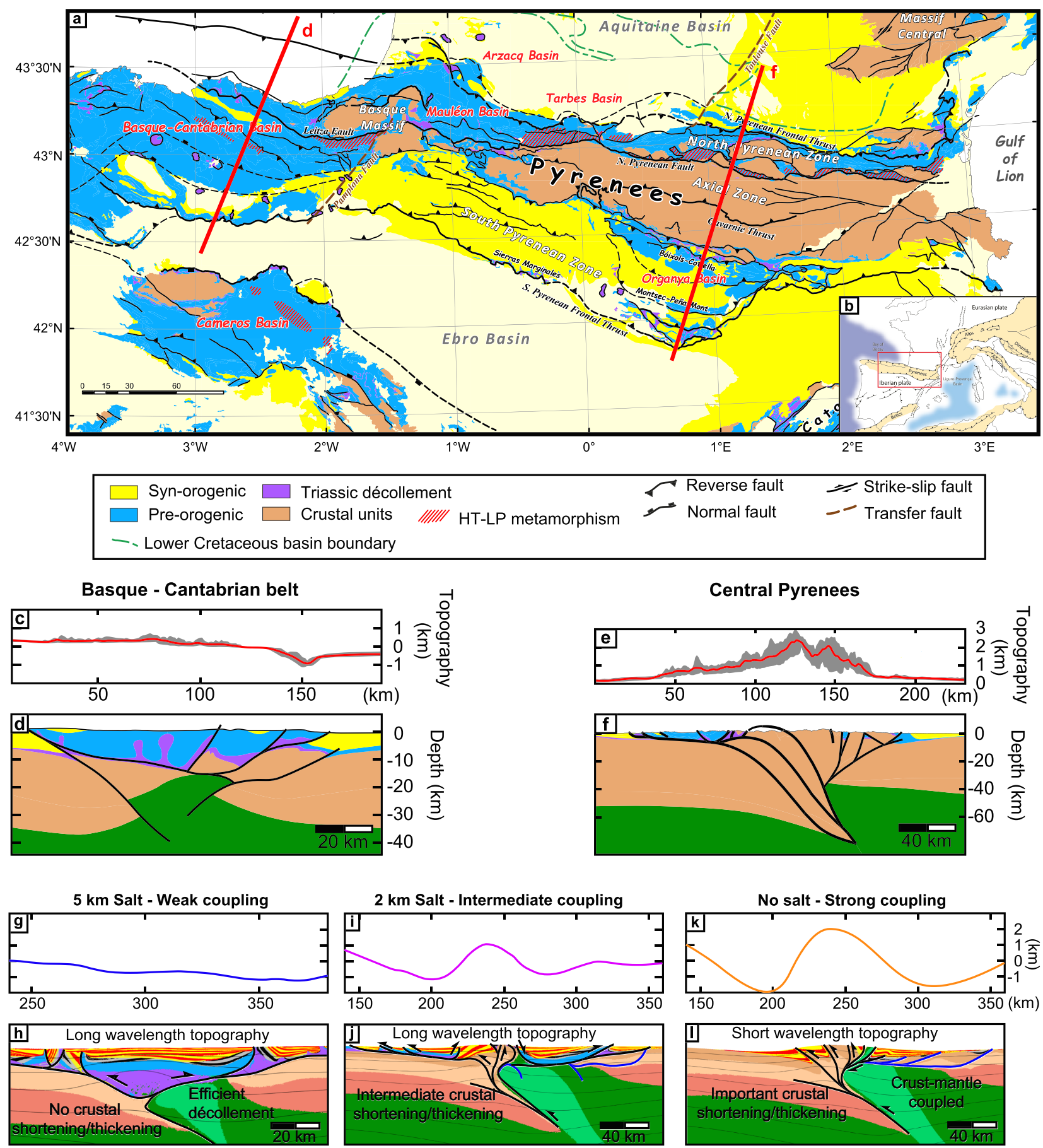

Continental crust Mantle

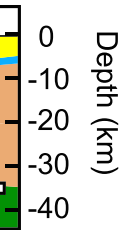

Figure 6. (a) Simplified geological map of the Pyrenean Orogen (modified after Pedrera et al., 2017, and Ducoux et al., 2019). (b) Simplified structural map of the Alpine orogens in the western Mediterranean zone (modified after Ducoux et al., 2019). (c) Topography of the Basque-Cantabrian belt. (d) Simplified geological cross section of the eastern Basque-Cantabrian belt redrawn after Càmara (2017), Pedrera et al. (2017), and Serrano et al. (1989). (e) Topography of the Central Pyrenees. (f) Simplified geological cross section of the central Pyrenees redrawn after Mouthereau et al. (2014). (g, i, and k) Topography at 85 Myr for each numerical model. Final state of the numerical models illustrating (h) a decoupled system, (j) an intermediate coupled system, and (l) a coupled system. Those illustrations are represented for a same amount of shortening 


\section{Conclusion}

Our modeling approach provides results that likely apply to a wide range of collisional orogens, involving a weak, prekinematic, décollement. The salt is found to play a first-order role in the topographic evolution of orogenic belts at lithospheric scale. The presence of a salt décollement indeed promotes the strain propagation and modifies the amplitude and wavelengths of syn-collisional basins and ranges. Regarding the general structure of the orogen, an absence of salt or a moderately thick intermediate salt layer favors the formation of an orogenic wedge by allowing antiformal-stack crustal wedge to form. Discontinuities in salt thickness induced by extension are shown to have little impact on the orogenic growth as a weak basal ductile décollement that localized strain is maintained during collision. To the contrary, a thick salt layer promotes the outward flow at the base of the thrust wedge promoting salt diapirism instead of classical thrust fault propagation. Depending on the initial thickness of salt, the timing of foreland basins formation and the preservation of associated syn-orogenic deposits strongly differ. The thicker the salt layer, the longer the delay between the onset of far-field shortening and the formation of the orogen. This study emphasizes that collision may involve a significant period of submarine continental accretion, which duration is controlled by the rheology of weak intermediate crustal layers. We conclude that the effect of salt on the time lag between (1) onset of shortening and (2) onset of thrust-related exhumation and deposition in foreland basins has likely been preponderant in the Pyrenees. This process may apply to many other collision zones where weak salt layers and/or décollement levels are recognized.

\section{Appendix A}

The thermo-mechanical models presented in the main article were performed with pTatin, a parallel implementation of finite element method, which employs an Arbitrary Lagrangian Eulerian discretization, together with the material point method. The codes solve for conservation of momentum

$$
\nabla . \sigma+\rho_{e f f} \mathbf{g}=0
$$

for a viscous material of density $\rho_{\text {eff }}$, assuming that the full stress tensor

$$
\sigma=\sigma^{\mathbf{d}}-\mathbf{I} P
$$

is the sum of deviatoric stress $\sigma^{\mathbf{d}}$ and an isotropic pressure term $P$. For a material of effective viscosity $\eta_{e f f}$, the deviatoric stress depends on strain rate

$$
\sigma^{\mathbf{d}}=2 \eta_{e f f} \dot{\varepsilon}^{\prime}
$$

As we assume that mass conservation is approximated by an incompressible flow that is

$$
\nabla \cdot \mathbf{v}=0
$$

The code is also coupled explicitly to heat conservation equation

$$
\frac{\partial T}{\partial t}+\boldsymbol{v} \cdot \nabla T=\kappa T+\frac{H}{C p}
$$

in order to solve for temperature $T$ using a constant thermal diffusivity $\kappa$. The heat source $H$ is a sum of the radiogenic heat production $\mathrm{Hr}$ and the shear heating heat production Hs such that

$$
H s=f \frac{W s}{\rho_{e f f} C p},
$$

where $f$ is a scale factor allowing varying the quantity of work converted in heat. Ws is the work produced by mechanical shearing: 


$$
W S=2 \eta_{e f f} \dot{\varepsilon}^{2} .
$$

The free surface boundary condition is accurately resolved through the use of high-order stable elements $\left(Q_{2}-P_{1}\right)$.

Material properties and history variables are assigned to material points contained within the computational domain that are advected with the velocity field of the solution. Effective viscosity is evaluated on material points using

$$
\eta_{\text {effd }}=\frac{1}{4}(\dot{\varepsilon})^{\frac{1}{n}-1}\left(\frac{3}{4} A\right)^{\frac{-1}{n}} e^{\frac{Q+P V^{*}}{n R T}},
$$

where coefficients $A, n$, and $Q$ define typical dislocation creep law and $V^{*}$, the activation volume, permits to increase activation energy with pressure.

If the deviatoric stress (equation (A3)) predicted by dislocation creep exceed the Drucker-Prager yield criterion as expressed here as a function of friction angle $\phi$ and cohesion $C$, the effective viscosity is re-evaluated as follows:

$$
\begin{aligned}
& \eta_{e f f p}=\frac{P \sin \phi+C \cos \phi}{\dot{\varepsilon}^{I I}}, \\
& \eta_{\text {eff }}=\min \left(\eta_{\text {effp }}, \eta_{\text {effd }}\right) .
\end{aligned}
$$

Effective density of material points, that is,

$$
\rho_{\text {eff }}=\rho_{0}\left[1-\alpha\left(T-T_{0}\right)+\beta\left(P-P_{0}\right)\right]
$$

depends on a constant term $\rho_{0}$ defined by the lithology and varies linearly on pressure and temperature, where $\alpha$ and $\beta$ are the coefficients of thermal expansion and adiabatic compressibility, respectively. We assume that these variations are small enough to be compatible with our equation for the conservation of mass (equation (A4)).

After being evaluated on material points, both viscosity and the density are then projected to the gauss points using $Q_{1}$ basis function together with harmonic and arithmetic averaging, respectively.

Damage on faults is implemented through linear decrease of friction and/or cohesion coefficients with accumulated plastic strain $\epsilon$

$$
\phi=\max \left(\phi_{\infty}, \phi_{0}-\frac{\epsilon\left(\phi_{0}-\phi_{\infty}\right)}{\epsilon_{\infty}}\right)
$$

$\mathrm{C}_{0} / \phi_{0}, \mathrm{C}_{\infty} / \phi_{\infty}$, and $\epsilon_{\infty}$ are, respectively, the initial (undamaged) cohesion/friction, the cohesion/friction at the end of the softening, and the characteristic plastic strain after which final softening is achieved.

At each time step, material points of sediment type are inserted on the current free surface; a new surface is computed according to Culling (1965) law:

$$
\frac{\partial \mathrm{h}}{\partial \mathrm{t}}=\nabla \cdot\left(\kappa_{\mathrm{e}} \nabla \mathrm{h}\right)
$$

The top surface is then remeshed so that only the sedimented markers remain. Sediment markers are given an age that corresponds to the time of deposition. This allows representing crude stratigraphic information.

Details on implementation are similar to the 3-D version of the code (Le Pourhiet et al., 2017; May et al., 2014, 2015). In 2-D, however, the linearized system of equation is small enough to be resolved with a direct sparse solver (umfpack) available through PETSc (Balay et al., 2013, 2014).

pTatin2D is an open source code, which is available publicly (at: https://bitbucket.org/ptatin/ptatin2d/). 


\section{Acknowledgments}

This study is part of the Orogen program, a tripartite research collaboration between CNRS, BRGM, and TOTAL SA. All authors are employed of French public research institutes. Dr. A. Jourdon is a postdoctoral employee of CNRS (French National Research Center) financed by the Orogen program. All other authors are employed by the French ministry of research. pTatin2D is an open source code, which is available publicly (at https://bitbucket. org/ptatin/ptatin2d/). Experiments are reproducible using the driver pTatin_two_stage.app and the options files jourdon_no_salt.opts, jourdon_2km_salt.opts, and jourdon_5km_salt.opts. We thank the editor Laurent Jolivet and the associate editor Laurent Husson. We also thank the two reviewers Armel Menant and Bruno Vendeville for their constructive remarks.

\section{References}

Angrand, P., Ford, M., \& Watts, A. B. (2018). Lateral variations in foreland flexure of a rifted continental margin: The Aquitaine Basin (SW France). Tectonics, 37(2), 430-449. https://doi.org/10.1002/2017TC004670

Balay, S., Abhyankar, S., Adams, M. F., Brown, J., Brune, P., Buschelman, K., et al. (2013). PETSc Web page. Computer Science Division, Argonne National Laboratory.

Balay, S., Abhyankar, S., Adams, M., Brown, J., Brune, P., Buschelman, K., ... Zhang, H. (2014). PETSc Users Manual, (June). Argonne National Laboratory.

Ballato, P., Mulch, A., Landgraf, A., Strecker, M. R., Dalconi, M. C., Friedrich, A., \& Tabatabaei, S. H. (2010). Middle to late Miocene Middle Eastern climate from stable oxygen and carbon isotope data, southern Alborz mountains, N Iran. Earth and Planetary Science Letters, 300(1-2), 125-138. https://doi.org/10.1016/j.epsl.2010.09.043

Brun, J. P., \& Fort, X. (2011). Salt tectonics at passive margins: Geology versus models. Marine and Petroleum Geology, $28,1123-1145$. https://doi.org/10.1016/j.marpetgeo.2011.03.004

Brune, S., Heine, C., Pérez-Gussinyé, M., \& Sobolev, S. V. (2014). Rift migration explains continental margin asymmetry and crustal hyperextension. Nature Communications, 5(1), 1-9. https://doi.org/10.1038/ncomms5014

Buiter, S. J. H., Adrian, O. P., \& Beaumont, C. (2009). Inversion of extensional sedimentary basins: A numerical evaluation of the localisation of shortening. Earth and Planetary Science Letters, 288, 492-504. https://doi.org/10.1016/j.epsl.2009.10.011

Burov, E., \& Yamato, P. (2008). Continental plate collision, P-T-t-z conditions and unstable vs. stable plate dynamics: Insights from thermomechanical modelling. Lithos, 103(1-2), 178-204. https://doi.org/10.1016/j.lithos.2007.09.014

Callot, J., Trocmé, V., Letouzey, J., Albouy, E., Jahani, S., \& Sherkati, S. (2012). Pre-existing salt structures and the folding of the Zagros Mountains. In G. I. Alsop, S. G. Archer, A. J. Hartley, N. T. Grant, \& R. Hodgkinson (Eds.), Salt Tectonics, Sediments and Prospectivity (pp. 545-561). The Geological Society of London. https://doi.org/10.1144/SP363.27

Càmara, P. (2017). Salt and strike-slip tectonics as main drivers in the structural evolution of the Basque-Cantabrian Basin, Spain. In J. I Soto, J. F. Flinch, \& G. Tari (Eds.), Permo-Triassic salt provinces of Europe, North Africa and the Atlantic Margins (pp. 371-393). Candice Janco). Amsterdam: Elsevier. https://doi.org/10.1016/B978-0-12-809417-4.00018-5

Càmara, P., \& Flinch, J. F. (2017). The southern Pyrenees: A salt-based fold-and-thrust belt. In J. I. Soto, J. F. Flinch, \& G. Tari (Eds.), Permo-Triassic salt provinces of Europe, North Africa and the Atlantic Margins (pp. 395-415). Candice Janco). Amsterdam: Elsevier. https://doi.org/10.1016/B978-0-12-809417-4.00019-7

Canérot, J., Hudec, M. R., \& Rockenbauch, K. (2005). Mesozoic diapirism in the Pyrenean orogen: Salt tectonics on a transform plate boundary. AAPG Bulletin, 2(2), 211-229. https://doi.org/10.1306/09170404007

Clerc, C., \& Lagabrielle, Y. (2014). Thermal control on the modes of crustal thinning leading to mantle exhumation: Insights from the cretaceous pyrenean hot paleomargins. Tectonics, 33(7), 1340-1359. https://doi.org/10.1002/2013TC003471

Costa, E., \& Vendeville, B. (2002). Experimental insights on the geometry and kinematics of fold-and-thrust belts above weak, viscous evaporitic décollement. Journal of Structural Geology, 24, 1729-1739. https://doi.org/10.1016/S0191-8141(01)00169-9

Culling, W. E. H. (1965). Theory of erosion on soil-covered slopes. The Journal of Geology, 73(2), 230-254. https://doi.org/10.1086/627060

Davis, D. M., \& Engelder, T. (1985). The role of salt in folds-and-thrust belts. Tectonophysics, 119, 67-88. https://doi.org/10.1016/0040-1951 (85)90033-2

DeFelipe, I., Pedreira, D., Pulgar, J. A., van der Beek, P. A., Bernet, M., \& Pik, R. (2019). Unraveling the Mesozoic and Cenozoic tectonothermal evolution of the Eastern Basque-Cantabrian Zone-Western Pyrenees by low-temperature thermochronology. Tectonics, 38 1-26. https://doi.org/10.1029/2019TC005532

Ducoux, M., Jolivet, L., Callot, J.-P., Aubourg, C., Masini, E., Lahfid, A., et al. (2019). The Nappe des Marbres unit of the Basque-Cantabrian Basin: The tectono-thermal evolution of a fossil hyperextended rift basin. Tectonics, 38(11), 3881-3915. https://doi.org/10.1029/ 2018 TC005348

Duretz, T., Asti, R., Lagabrielle, Y., Brun, J. P., Jourdon, A., Clerc, C., \& Corre, B. (2019). Numerical modelling of Cretaceous Pyrenean Rifting: The interaction between mantle exhumation and syn - rift salt tectonics. Basin Research, (June), 1-16. https://doi.org/10.1111/ bre.12389

Espurt, N., Angrand, P., Teixell, A., Labaume, P., Ford, M., Blanquat, M., et al. (2019). Crustal-scale balanced cross-section and restorations of the Central Pyrenean belt (Nestes-Cinca transect): Highlighting the structural control of Variscan belt and Permian-Mesozoic rift systems on mountain building. Tectonophysics, 764(April), 25-45. https://doi.org/10.1016/j.tecto.2019.04.026

Ford, M. (2004). Depositional wedge tops: Interaction between low basal friction external orogenic wedges and flexural foreland basins. Basin Research, 16(3), 361-375. https://doi.org/10.1111/j.1365-2117.2004.00236.x

Gradmann, S., \& Beaumont, C. (2017). Numerical modelling study of mechanisms of mid-basin salt canopy evolution and their potential applications to the Northwestern Gulf of Mexico. Basin Research, 29, 490-520. https://doi.org/10.1111/bre.12186

Granado, P., Roca, E., Strauss, P., Pelz, K., \& Muñoz, J. A. (2019). Structural styles in fold-and-thrust belts involving early salt structures: The Northern Calcareous Alps (Austria). Geology, 47(1), 1-4. https://doi.org/10.1130/G45281.1/4578624/g45281.pdf

Grelaud, S., Sassi, W., de Lamotte, D. F., Jaswal, T., \& Roure, F. (2002). Kinematics of eastern Salt Range and South Potwar Basin (Pakistan): A new scenario. Marine and Petroleum Geology, 19(9), 1127-1139. https://doi.org/10.1016/S0264-8172(02)00121-6

Jammes, S., \& Huismans, R. S. (2012). Structural styles of mountain building: Controls of lithospheric rheologic stratification and extensional inheritance. Journal of Geophysical Research, 117, 1-22. https://doi.org/10.1029/2012JB009376

Jammes, S., Manatschal, G., Lavier, L., \& Masini, E. (2009). Tectonosedimentary evolution related to extreme crustal thinning ahead of a propagating ocean: Example of the western Pyrenees. Tectonics, 28(4), 1-24. https://doi.org/10.1029/2008TC002406

Jourdon, A., Le Pourhiet, L., Petit, C., \& Rolland, Y. (2018). Impact of range-parallel sediment transport on 2D thermo-mechanical models of mountain belts: Application to the Kyrgyz Tien Shan. Terra Nova. https://doi.org/10.1111/ter.12337

Jourdon, A., Le Pourhiet, L., Mouthereau, F., \& Masini, E. (2019). Role of rift maturity on the architecture and shortening distribution in mountain belts. Earth and Planetary Science Letters, 512, 89-99. https://doi.org/10.1016/j.epsl.2019.01.057

Konstantinovskaya, E., \& Malavieille, J. (2011). Thrust wedges with décollement levels and syntectonic erosion: A view from analog models. Tectonophysics, 502(3-4), 336-350. https://doi.org/10.1016/j.tecto.2011.01.020

Lagabrielle, Y., Labaume, P., \& De Saint Blanquat, M. (2010). Mantle exhumation, crustal denudation, and gravity tectonics during Cretaceous rifting in the Pyrenean realm (SW Europe): Insights from the geological setting of the lherzolite bodies. Tectonics, 29(4), 1-26. https://doi.org/10.1029/2009TC002588

Lavier, L. L., \& Manatschal, G. (2006). A mechanism to thin the continental lithosphere at magma-poor margins. Nature, 440(7082), 324-328. https://doi.org/10.1038/nature04608 
Le Pourhiet, L., May, D. A., Huille, L., Watremez, L., \& Leroy, S. (2017). A genetic link between transform and hyper-extended margins. Earth and Planetary Science Letters, 465, 184-192. https://doi.org/10.1016/j.epsl.2017.02.043

Legeay, E., Pichat, A., Kergaravat, C., Ribes, C., Callot, J.-P., Ringenbach, J.-C., et al. (2018). Geology of the Central Sivas Basin (Turkey). Journal of Maps, 15, 406-417. https://doi.org/10.1080/17445647.2018.1514539

Lopez-Mir, B., Muñoz, J. A., \& Senz, J. G. (2014). Restoration of basins driven by extension and salt tectonics: Example from the Cotiella Basin in the central Pyrenees. Journal of Structural Geology, 69(December), 147-162. https://doi.org/10.1016/j.jsg.2014.09.022

Malavieille, J. (2010). Impact of erosion, sedimentation, and structural heritage on the structure and kinematics of orogenic wedges: Analog models and case studies. GSA Today, 20(1). https://doi.org/10.1130/GSATG48A.1

May, D. A., Brown, J., \& Le Pourhiet, L. (2014). pTatin3D: High-performance methods for long-term lithospheric dynamics. In Proceeding SC'14 Proceedings of the International Conference for High Performance Computing, Networking, Storage and Analysis (pp. 274-284). New Orleans: IEEE Press.

May, D. A., Brown, J., \& Le Pourhiet, L. (2015). A scalable, matrix-free multigrid preconditioner for finite element discretizations of heterogeneous Stokes flow. Computer Methods in Applied Mechanics and Engineering, 290, 496-523. https://doi.org/10.1016/j. cma.2015.03.014

McClay, K., Munoz, J. A., \& García-Senz, J. (2004). Extensional salt tectonics in a contractional orogen: A newly identified tectonic event in the Spanish Pyrenees. Geology, 32(9), 737-740. https://doi.org/10.1130/G20565.1

Mesalles, L., Mouthereau, F., Bernet, M., Chang, C., Lin, A. T., Fillon, C., \& Sengelen, X. (2014). From submarine continental accretion to arc-continent orogenic evolution: The thermal record in southern Taiwan. Geology, 42(10), 907-910. https://doi.org/10.1130/G35854.1

Mouthereau, F., Lacombe, O., \& Vergés, J. (2012). Building the Zagros collisional orogen: Timing, strain distribution and the dynamics of Arabia/Eurasia plate convergence. Tectonophysics, 532-535, 27-60. https://doi.org/10.1016/j.tecto.2012.01.022

Mouthereau, F., Filleaudeau, P. Y., Vacherat, A., Pik, R., Lacombe, O., Fellin, M. G., et al. (2014). Placing limits to shortening evolution in the Pyrenees: Role of margin architecture and implications for the Iberia/Europe convergence. Tectonics, 33(12), 2283-2314. https://doi. org/10.1002/2014TC003663

Munoz, J. A. (1992). Evolution of a continental collision belt: ECORS-Pyrenees crustal balanced cross-section. In K. R. McClay (Ed.), Thrust tectonics (pp. 235-246). Dordrecht: Springer.

Pedrera, A., Garcia-Senz, C., Ayala, C., Ruiz-Constán, A., Rodríguez-Fernández, L. R., Robador, A., \& González Menéndez, L. (2017). Reconstruction of the exhumed mantle across the North Iberian margin by crustal-scale 3-d gravity inversion and geological cross section. Tectonics, 36, 3155-3177. https://doi.org/10.1002/2017TC004716

Reston, T. J., \& Mcdermott, K. G. (2011). Successive detachment faults and mantle unroofi ng at magma-poor rifted margins. Geology, 39(11), 1071-1074. https://doi.org/10.1130/G32428.1

Rowan, M. G. (2014). Passive-margin salt basins: Hyperextension, evaporite deposition, and salt tectonics. Basin Research, 26, 154-182. https://doi.org/10.1111/bre.12043

Saura, E., Ardèvol, I., Oró, L., Teixell, A., \& Vergés, J. (2016). Rising and falling diapirs, shifting depocenters, and flap overturning in the Cretaceous Sopeira and Sant Gervàs subbasins (Ribagorça Basin, southern Pyrenees). Tectonics, 35(3), 638-662. https://doi.org/10.1002/ 2015 TC004001

Sauter, D., Cannat, M., Rouméjon, S., Andreani, M., Birot, D., Bronner, A., et al. (2013). Continuous exhumation of mantle-derived rocks a the Southwest Indian Ridge for 11 million years. Nature Geoscience, 6(4), 314-320. https://doi.org/10.1038/ngeo1771

Serrano, O. A., Martínez del Olmo, W., \& Cámara, P. (1989). Diapirismo del Trías salino en el dominio Cántabro-Navarro. In AGGEP (Ed.), Libro Homenaje a Rafael Soler (pp. 115-121). AGGEP, Madrid.

Smit, J. H. W., Brun, J. P., \& Sokoutis, D. (2003). Deformation of brittle-ductile thrust wedges in experiments and nature. Journal of Geophysical Research, 108(B10). https://doi.org/10.1029/2002jb002190

Soto, J. I., Flinch, J. F., \& Tari, G. (2017). In J. I. Soto, J. F. Flinch, \& G. Tari (Eds.), Permo-Triassic salt provinces of Europe, North Africa and the Atlantic Margins. Amsterdam: Elsevier.

Teixell, A., Labaume, P., Ayarza, P., Espurt, N., de Saint Blanquat, M., \& Lagabrielle, Y. (2018). Crustal structure and evolution of the Pyrenean-Cantabrian belt: A review and new interpretations from recent concepts and data. Tectonophysics, 724-725, 146-170. https:// doi.org/10.1016/j.tecto.2018.01.009

Vacherat, A., Mouthereau, F., Pik, R., Bellahsen, N., Gautheron, C., Bernet, M., et al. (2016). Rift-to-collision transition recorded by tectonothermal evolution of the northern Pyrenees. Tectonics, 35, 907-933. https://doi.org/10.1002/2015TC004016

Wang, Y., Chevrot, S., Monteiller, V., Komatitsch, D., Mouthereau, F., \& Manatschal, G. (2016). The deep roots of the western Pyrenees revealed by full waveform inversion of teleseismic $P$ waves. Geology, 44(6), 475-478. https://doi.org/10.1130/G37812.1 